Gunnar Selvik - Michael-James Clifton Theresa Haas · Luísa Lourenço Kerstin Schwiesow Editors
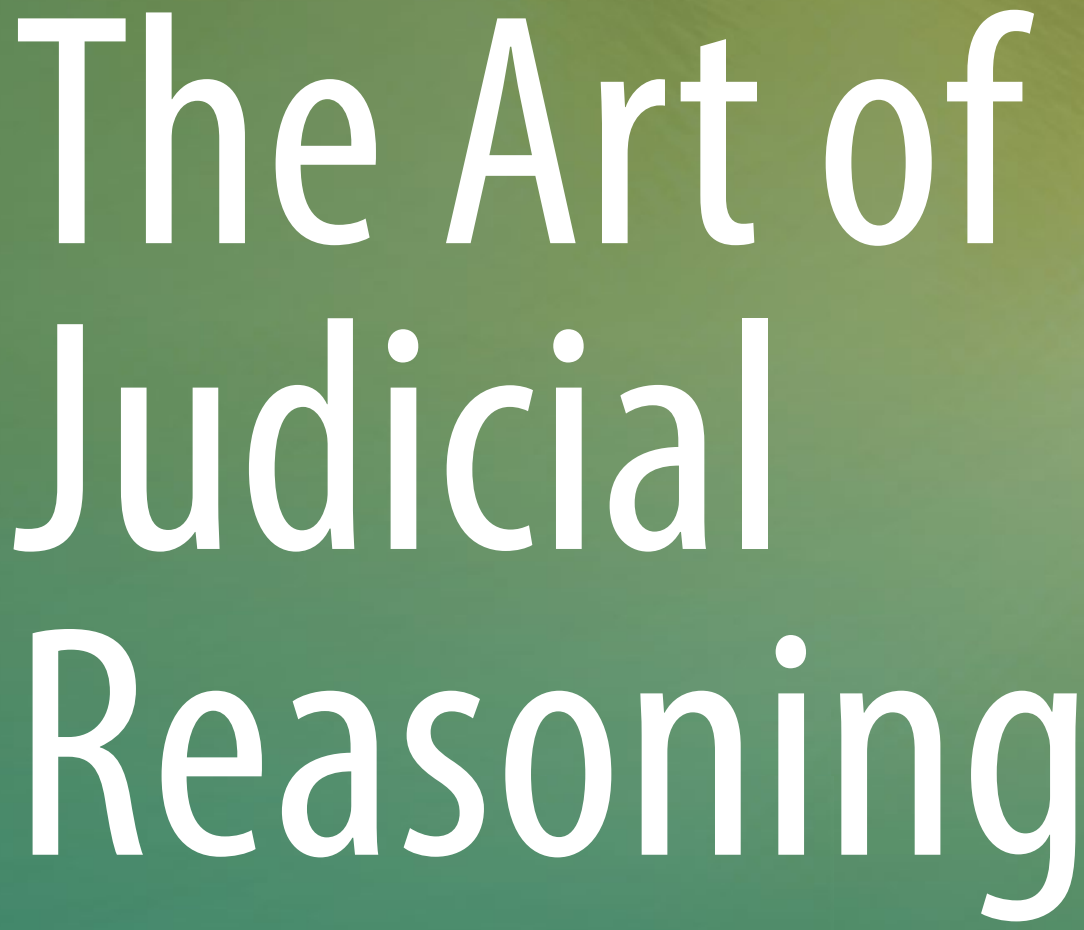

Festschrift in Honour of Carl Baudenbacher

Springer 


\section{Editors}

Gunnar Selvik

EFTA Court

Luxembourg City, Luxembourg

Theresa Haas

EFTA Court

Luxembourg City, Luxembourg

Kerstin Schwiesow

EFTA Court

Luxembourg City, Luxembourg

\author{
Michael-James Clifton \\ EFTA Court \\ Luxembourg City, Luxembourg
}

Luísa Lourenço

EFTA Court

Luxembourg City, Luxembourg

\footnotetext{
ISBN 978-3-030-02552-6 ISBN 978-3-030-02553-3 (eBook)

https://doi.org/10.1007/978-3-030-02553-3
}

Library of Congress Control Number: 2018960255

(C) Springer Nature Switzerland AG 2019

This work is subject to copyright. All rights are reserved by the Publisher, whether the whole or part of the material is concerned, specifically the rights of translation, reprinting, reuse of illustrations, recitation, broadcasting, reproduction on microfilms or in any other physical way, and transmission or information storage and retrieval, electronic adaptation, computer software, or by similar or dissimilar methodology now known or hereafter developed.

The use of general descriptive names, registered names, trademarks, service marks, etc. in this publication does not imply, even in the absence of a specific statement, that such names are exempt from the relevant protective laws and regulations and therefore free for general use.

The publisher, the authors and the editors are safe to assume that the advice and information in this book are believed to be true and accurate at the date of publication. Neither the publisher nor the authors or the editors give a warranty, express or implied, with respect to the material contained herein or for any errors or omissions that may have been made. The publisher remains neutral with regard to jurisdictional claims in published maps and institutional affiliations.

This Springer imprint is published by the registered company Springer Nature Switzerland AG The registered company address is: Gewerbestrasse 11, 6330 Cham, Switzerland 


\title{
On Judicial Independence and the Quest for National, Supranational and Transnational Justice
}

\author{
Koen Lenaerts
}

\section{Introduction}

For centuries, judges, lawyers and legal scholars have read the law, examined the case law and studied the text books with the same objective in mind, that of finding justice. It is this quest for justice - our "Holy Grail" as one might call it - that defines the legal profession in its mission to pass on a fairer and more equal society for the next generation.

As defined by the constitutional traditions common to the Member States of the European Union, democracies are built on the understanding that, regardless of their political affiliation, religious beliefs and cultural heritage, individuals enjoy a sphere of self-determination that must, at all times, be free from public or, as the case may be, private interference.

This means, in practice, that the incumbent political majority is prevented, by constitutional law, from oppressing individuals that belong to discrete minorities that lack the means to defend themselves within the political process. That is also why the constitutions of the Member States entrust courts - as independent umpires - with the task of protecting that individual sphere of self-determination. In Europe, the idea of justice is therefore deeply intertwined with that of upholding individual rights.

This shows the link between individual rights, democracy and justice that is embedded in those constitutional traditions: democracies are only as strong as the protection that they provide to individual rights. The more effective that protection is, the stronger democracy will be. At the same time, the effectiveness of that protection depends on the independence of judges. Indeed, the more robust judges are in

President of the Court of Justice of the European Union, Professor of European Union Law at the University of Leuven (Belgium).

K. Lenaerts $(\square)$

Court of Justice of the European Union, Luxembourg City, Luxembourg 
carrying out their duties without fear nor favour, the more effective the protection of individual rights is, and the stronger democracy will be.

The independence of the national judiciary not only contributes to reinforcing national democracies individually, but also when acting collectively within the framework of the EU in order to achieve common objectives.

In both the Member States and the EU, respect for the rule of law means no more and no less than respect for judicial decisions, especially in cases where a court does not rule in favour of the incumbent political majority of the moment. For example, it was the need to ensure the effectiveness of final judicial decisions and thus, the need to uphold the rule of law within the EU, that led the European Court of Justice ("ECJ") to hold in Commission v Poland that the adoption of interim measures may be accompanied by the imposition of a periodic penalty payment in the event that those measures would not be complied with. ${ }^{1}$ Such imposition is not to be seen as a sanction, but as a means of ensuring the effective application of EU law in cases where there are grounds for doubting that the Member State concerned has complied with a previous interim relief order or that it is prepared to comply with a new order. $^{2}$

As Chief Justice Marshall famously wrote in the legendary Marbury v Madison case more than two centuries ago, "[it] is emphatically the province and duty of the judicial department to say what the law is." ${ }^{3}$ If we, the peoples of Europe, want governments of laws and not men, we must, first and foremost, honour what judges say about the law. This is, in my view, how real European democracies work and must continue to work in the future. That is the reason why judicial independence is of pivotal importance, since it ensures that judges remain faithful to the law and only to the law. Judicial independence is the bedrock of our democracies, be it at national or European level. One may go as far as to say that judicial independence is part of both our common heritage and of our very identity as Europeans.

The same applies to the European Economic Area ("EEA") where the rule of law is centre stage in that system of decentralised integration. ${ }^{4}$ The purpose of this essay is to pay tribute to Carl Baudenbacher, President of the EFTA Court from 2003 to 2017, whose legacy to the legal community, both as judge and as a legal scholar, is of immense value. My contribution is structured as follows. Section 2 looks at judicial independence from a supranational perspective. In light of the relevant case law of the ECJ, it is submitted that judicial independence is of paramount importance for the law of the EU, given that access to the preliminary reference procedure - a procedure that ensures the uniform application of that law - is only open to independent courts. That is the reason why in the recent judgment of the ECJ in Associação Sindical dos Juizes Portugueses, that court held that EU law protects the independence of national courts, since it is an essential prerequisite for the judicial dialogue

\footnotetext{
${ }^{1}$ ECJ order of 20 November 2017 in case C-441/17 R, Commission v Poland, EU:C:2017:877.

${ }^{2}$ Ibid., paras 102, 103, and 109.

${ }^{3}$ US Supreme Court, Marbury v. Madison, 5 U.S. (1 Cranch) 137 (1803).

${ }^{4}$ See generally EFTA Court (eds) (2015) The EEA and the EFTA Court: Decentred Integration.
} 
between the ECJ and the national courts. ${ }^{5}$ Section 3 is devoted to another recent judgment of the ECJ in Achmea, which reflects the objective of protecting the integrity of that dialogue. This case concerned an arbitration clause contained in a Bilateral Investment Treaty ("BIT"). ${ }^{6}$ In Sect. 4, it is argued that the objective of creating an Area of Freedom, Security and Justice ("AFSJ") is to be achieved by relying on judicial cooperation in civil and criminal matters. Such cooperation requires independent national courts that trust each other as being equally committed to upholding the rule of law. ${ }^{7}$ Thus, from a transnational perspective, the principles of mutual trust and judicial independence go hand in hand. Finally, a brief conclusion supports the contention that the ECJ is committed to protecting the independence of national courts as such protection is vital to upholding the rule of law within the EU.

\section{Judicial Independence and the Effective Protection of EU Rights}

\subsection{Judicial Independence and the Notion of 'Court or Tribunal' Within the Meaning of Article 267 TFEU}

From a supranational perspective, national courts play a vital role in securing effective protection of the rights that EU law confers on individuals. Those courts are, in cooperation with the ECJ, to enforce the law of the EU so as to provide effective remedies against defaulting Member States and against EU institutions that have acted in breach of the Treaties and/or the Charter of Fundamental Rights of the European Union ("Charter"). ${ }^{8}$

To that end, the ECJ has held that, by virtue of EU law, national courts are, for example, empowered to set aside a provision of national law that is incompatible with EU law, even if that provision enjoys constitutional status under the laws of the Member State concerned. ${ }^{9}$ National courts may also grant interim relief so as to ensure that EU rights are preserved before it is too late..$^{10}$ In the same way, a person

\footnotetext{
${ }^{5}$ ECJ judgment of 27 February 2018 in case C-64/16, Associação Sindical dos Juízes Portugueses, EU:C:2018:117.

${ }^{6} \mathrm{ECJ}$ judgment of 6 March 2018 in case C-284/16, Achmea, EU:C:2018:158.

${ }^{7}$ See generally Lenaerts (2017), pp. 805-840.

${ }^{8}$ See generally De Witte et al. (2016).

${ }^{9}$ See, e.g., ECJ judgments of 9 March 1978 in case 106/77, Simmenthal, EU:C:1978:49, and of 8 September 2010 in case C-409/06, Winner Wetten, EU:C:2010:503.

${ }^{10}$ Regarding interim relief against national measures, see, e.g., ECJ judgment of 19 June 1990 in case C-213/89, Factortame and Others, EU:C:1990:257. As to EU measures, see ECJ judgment of 21 February 1991 in joined cases C-143/88 and C-92/89, Zuckerfabrik Süderdithmarschen and Zuckerfabrik Soest, EU:C:1991:65.
} 
may also claim compensation before a national court for the harm that a defaulting Member State or an individual has caused to his or her EU rights. ${ }^{11}$

Given that each and every EU citizen is entitled to the same rights, it is of paramount importance that national courts apply EU law in a uniform fashion. With a view to ensuring that uniformity, and when experiencing doubts as to the interpretation of a provision of EU law, national courts are to engage in a dialogue with the ECJ by having recourse to the preliminary reference procedure. To put it in the ECJ's own words, "the [EU] judicial system [...] has as its keystone the preliminary ruling procedure provided for in Article 267 TFEU, which, by setting up a dialogue between one court and another, specifically between the [ECJ] and the courts and tribunals of the Member States, has the object of securing uniform interpretation of EU law". 12

That same imperative of uniformity applies where a national court has serious doubts as to the legality of an act adopted by the institutions, bodies, offices or agencies of the Union. That is why national courts are precluded from exercising jurisdiction in respect of the legality of such an act. Instead, they are required to make a reference to the ECJ which has the power to review the legality of EU acts. In that regard, that Court has held that "requests for preliminary rulings which seek to ascertain the validity of a measure constitute, like actions for annulment, a means for reviewing the legality of European Union acts". ${ }^{13}$

It follows that national courts or tribunals, within the meaning of Article 267 TFEU, are, first and foremost, called upon to protect effectively the rights that EU law confers on individuals, thereby providing them with "supranational justice" and upholding the rule of law within the EU. In order to have access to the preliminary reference procedure national courts must be independent because only those courts can be trusted with applying loyally the law of the EU, as interpreted by the ECJ. The effective protection of EU rights indeed requires that the competent national court is insulated from any political pressure, notably on the part of the public authorities that brought about the breach of these rights.

The fact that the preliminary reference procedure is open only to independent courts stems from the fact that Article 267 TFEU refers explicitly to "any court or tribunal of a Member State". ${ }^{14}$ As understood by the ECJ, the notion of "court or tribunal" is an autonomous concept of EU law. ${ }^{15}$ This means that national law is not decisive in order to determine whether the body making a preliminary reference

\footnotetext{
${ }^{11}$ See, e.g., ECJ judgments of 19 November 1991 in joined cases C-6/90 and C-9/90, Francovich and Others, EU:C:1991:428; of 5 March 1996, in joined cases C-46/93 and C-48/93, Brasserie du Pêcheur and Factortame, EU:C:1996:79; of 20 September 2001 in case C-453/99, Courage and Crehan, EU:C:2001:465; of 30 September 2003 in case C-224/01, Köbler, EU:C:2003:513.

${ }^{12}$ ECJ Opinion 2/13 (Accession of the European Union to the ECHR) of 18 December 2014, EU:C:2014:2454, para. 176.

${ }^{13}$ ECJ judgment of 28 March 2017 in case C-72/15, Rosneft, EU:C:2017:236, para. 68.

${ }^{14}$ See, generally, Broberg and Fenger (2014).

${ }^{15}$ See, e.g., ECJ judgment of 24 May 2016 in case C-396/14, MT Højgaard and Züblin, EU:C:2016:347, para. 23.
} 
qualifies as a "court or tribunal" under that Treaty provision. It is, however, relevant in verifying whether the factors to which EU law subjects the notion of "court or tribunal" are present.

It follows from settled case law that the ECJ "will take account of a number of factors, such as whether the body is established by law, whether it is permanent, whether its jurisdiction is compulsory, whether its procedure is inter partes, whether it applies rules of law and whether it is independent". ${ }^{16}$

The concept of judicial independence requires, in the administrative law context, that judicial power should be exercised by a body that acts as a third party in relation to the authority which adopted the contested decision. Thus, for example, in Devillers, the ECJ ruled that the Belgian Regional Council of the Society of Veterinary Doctors was not a third-party for the purposes of making a preliminary reference, since it was the body responsible for imposing disciplinary sanctions against the applicant in the main proceedings, i.e. a veterinarian who had allegedly violated the relevant rules of professional conduct. ${ }^{17}$

In addition, the concept of judicial independence, as developed in the seminal Wilson judgment, ${ }^{18}$ has both an internal and an external dimension. Internally, judicial independence is intended to ensure a level playing field for the parties to proceedings and for their competing interests. In other words, independence requires courts to be impartial.

Externally, judicial independence establishes the dividing line between the political process and the courts. Courts must be shielded from any external influence or pressure that might jeopardise the independent judgement of their members as regards proceedings before them. ${ }^{19}$ That protection must apply to the members of the judiciary, by, for example, laying down guarantees against removal from office. ${ }^{20}$ Thus, in Syfait, the ECJ held that in the absence of adequate safeguards in respect of the dismissal or termination of the appointment of "judges" belonging to the Greek competition authority, the rules governing their tenure did not appear to provide effective protection against undue intervention or pressure from the executive. ${ }^{21}$ Accordingly, that authority could not be seen as a "court or tribunal" within the meaning of Article 267 TFEU.

\footnotetext{
${ }^{16}$ See, for example, ECJ judgments of 30 June 1966 in case 61/65, Vaassen-Göbbels, EU:C:1966:39; of 10 December 2009 in case C-205/08, Umweltanwalt von Kärnten, EU:C:2009:767, para. 35; of 6 October 2015 in case C-203/14, Consorci Sanitari del Maresme, EU:C:2015:664, para. 17, and MT Højgaard and Züblin, cited above, para. 23.

${ }^{17}$ The ECJ noted that, whilst the member of that Council in charge of investigating the case did not participate in the deliberations, nor took part in the adoption of the final decision, there was a close functional link between him and that Council. See ECJ order of 28 November 2013 in case C-167/13, Devillers, not published, EU:C:2013:804, para. 19.

${ }^{18}$ ECJ judgment of 19 September 2006 in case C-506/04, Wilson, EU:C:2006:587, paras 49-52.

${ }^{19}$ Ibid., para. 51.

${ }^{20}$ See ECJ judgments of 22 October 1998, in joined cases C-9/97 and C-118/97, Jokela and Pitkäranta, EU:C:1998:497, para. 20, and judgment of 4 February 1999 in case C-103/97, Köllensperger and Atzwanger, EU:C:1999:52, para. 21.

${ }^{21}$ ECJ judgment of 31 May 2005 in case C-53/03, Syfait and Others, EU:C:2005:333, para. 31.
} 
Furthermore, the external aspect of judicial independence also requires the absence of any "hierarchical constraint or subordination to any other body that could give [...] orders or instructions" to the body making the reference. Therefore, in Margarit Panicello, the ECJ ruled that the Registrar ("Secretario Judicial") of a Spanish court did not constitute a "court or tribunal" within the meaning of Article 267 TFEU, since he or she was required to comply with instructions from a hierarchical superior when making a reference in the context of an action for the recovery of fees due for legal services. ${ }^{22}$

Similarly, the EFTA Court has ruled that only independent bodies may make a request for an Advisory Opinion under Article 34 SCA. ${ }^{23}$ In so doing, that Court has drawn inspiration from the case law of the ECJ when defining the notion of "court or tribunal" set out in that provision of the SCA. ${ }^{24}$ For example, in Inconsult Anstalt, the EFTA Court found that the Appeals Commission of the Financial Market Authority of Liechtenstein qualified as a "court or tribunal" for the purposes of Article 34 SCA. It noted that that Appeals Commission "[gave] rulings, without receiving any instructions and in total impartiality, on decisions adopted by the Financial Market Authority. In this respect the Appeals Commission has a status separate from the authority which adopted the decision under appeal". ${ }^{25}$

Once it has been established that the body making a reference qualifies as a "court or tribunal" within the meaning of Article 267 TFEU and, where appropriate, that of Article 34 SCA, that body may engage in a dialogue with the ECJ and, regarding Norwegian, Icelandic and Liechtenstein courts, with the EFTA Court. As mentioned above, that dialogue is of paramount importance since it ensures the uniform application of EU law.

\subsection{Article 19 TEU and the Protection of Judicial Independence}

Logically, the question that arises is whether, once it has been established that a body qualifies as a "court or tribunal" within the meaning of Article 267 TFEU, EU law may also protect that body against a national measure that threatens its

\footnotetext{
${ }^{22}$ ECJ judgment of 16 February 2017 in case C-503/15, Margarit Panicello, EU:C:2017:126, paras 41 and 42.

${ }^{23}$ See EFTA Court judgment of 16 December 1994 in case E-1/94, Restamark, [1994-95] EFTA Ct. Rep. 15, paras 24 et seq. See also EFTA Court judgment of 16 June 1995 in joined cases E-8/94 and E-9/94, Mattel and Lego [1994-95] EFTA Ct. Rep. 113.

${ }^{24}$ See Restamark, cited above, para. 24 (referring to ECJ judgment of 27 April 1994 in case C-393/92, Almelo, EU:C:1994:171, para. 21), and of 27 January 2010 in case E-4/09, Inconsult Anstalt, [2009-2010] EFTA Ct. Rep p. 88, para. 23 (referring to ECJ judgments of 17 September 1997 in case C-54/96, Dorsch Consult, EU:C:1997:413, para. 23 and of 14 June 2001 in case C-178/99, Salzman, EU:C:2001:331, para. 13).

${ }^{25}$ Inconsult Anstalt, cited above, para. 23.
} 
independence. Here, the focus is not on protecting judges as beneficiaries of fundamental rights, but on protecting judges as the arm of the law, i.e. of EU law.

\subsubsection{National Judges as Individuals}

Just like any other EU citizen or third-country national, national judges are protected by EU law in their individual capacity. Where a national measure that implements EU law adversely affects their fundamental rights, national judges may bring proceedings before the competent court, basing their application on the relevant provisions of the Charter. They may also base their application on EU legislation giving concrete expression to a fundamental right recognised in the Charter, such as the Discrimination Directives. ${ }^{26}$ The rulings of the ECJ in Florescu and Commission v Hungary illustrate this point.

In Florescu, ${ }^{27}$ five retired Romanian judges who also taught at university challenged a law that prohibited combining their pension with revenue from paid employment, where that pension was higher than the gross average national income. That law was the result of austerity measures that Romania had adopted in exchange for financial assistance granted by the EU. After finding that the law in question implemented EU law within the meaning of Article 51(1) of the Charter, the ECJ held that those judges could rely on their right to property, as enshrined in Article 17 of the Charter, in order to challenge the compatibility with EU law of the Romanian law. ${ }^{28}$ However, the ECJ found that, whilst that law imposed a limitation on the exercise of the applicant's right to property, it sought to pursue a legitimate objective, i.e. the need to reduce public spending in the exceptional circumstances of the global financial and economic crisis. ${ }^{29}$ Moreover, in the light of such exceptional circumstances, that limitation complied with the principle of proportionality. ${ }^{30}$

Similarly, in Commission v Hungary,${ }^{31}$ the ECJ held that Hungary had failed to fulfil its obligations under Directive $2000 / 78$ by adopting rules imposing compulsory retirement on judges, prosecutors and notaries on reaching the age of 62 . The ECJ found that those rules pursued two legitimate objectives, i.e. the standardisation, in the context of professions in the public sector, of the age-limit for compulsory retirement and the establishment of a "more balanced age structure" facilitating access for young lawyers to the professions of judge, prosecutor and notary. However, in so doing, those rules failed to comply with the principle of proportionality. ${ }^{32}$ In particular, the ECJ noted that the rules in question "abruptly and

\footnotetext{
${ }^{26}$ See e.g. Directive 2000/78/EC of 27 November 2000 establishing a general framework for equal treatment in employment and occupation, [2000] OJ L 303/16.

${ }^{27}$ ECJ judgment of 13 June 2017 in case C-258/14, Florescu and Others, EU:C:2017:448.

${ }^{28}$ Ibid., paras 48 and 49.

${ }^{29}$ Ibid., para. 56.

${ }^{30} \mathrm{Ibid}$., paras 57 and 58.

${ }^{31}$ ECJ judgment of 6 November 2012 in case C-286/12, Commission v Hungary, EU:C:2012:687.

${ }^{32}$ Ibid., para. 80.
} 
significantly lowered the age-limit for compulsory retirement [i.e. from the age of 70 to that of 62], without introducing transitional measures of such a kind as to protect the legitimate expectations of the persons concerned" and of such a kind as to enable them to make the necessary economic and financial arrangements. ${ }^{33}$

\subsubsection{National Judges as the Arm of EU Law}

Most importantly, as regards the protection of national judges in their role as the arm of EU law (or, put more simply, as "European judges"), the ECJ held in Associação Sindical dos Juízes Portugueses that the second subparagraph of Article 19(1) TEU may be relied upon in order to set aside national measures that call into question the independence of the national judiciary. ${ }^{34}$ The facts of that case are as follows.

In response to the EU programme of financial assistance and with a view to curtailing its excessive budget deficit, Portugal passed a law in 2014 that sought to cut public spending by reducing the salaries of various public office holders and employees, including members of the legislature, the executive and the judiciary. Such salary-reduction measures also applied to the members of the Portuguese Court of Auditors ("Tribunal de Contas"). The Union of Portuguese Judges, acting on behalf of those members, brought legal proceedings against the administrative acts implementing that law, arguing that those salary-reduction measures threatened the judicial independence of the said members, as guaranteed by Article 19 TEU and Article 47 of the Charter.

At the outset, the ECJ stressed the fact that the second subparagraph of Article 19(1) TEU applies ratione materiae to "the fields covered by EU law", irrespective of whether the Member States are implementing EU law within the meaning of Article 51(1) of the Charter. ${ }^{35} \mathrm{Next}$, the ECJ went on to explain the relationship between the rule of law, Article 19 TEU, the principle of effective judicial protection and national courts. It held that the EU is founded on the values set out in Article 2 TEU, such as respect for the rule of law. Article 19 TEU gives concrete expression to that founding value by entrusting "the responsibility for ensuring judicial review in the EU legal order not only to the [ECJ] but also to national courts and tribunals". ${ }^{36}$ Accordingly, the Member States are under the obligation "to establish a system of legal remedies and procedures ensuring effective judicial protection in [the fields covered by EU law]". ${ }^{37}$ In that regard, the ECJ found that there is an unbreakable link between compliance with the rule of law and the principle of effective judicial protection: one cannot exist without the other. The bodies entrusted with responsibility for upholding the rule of law within the EU - i.e.

\footnotetext{
${ }^{33}$ Ibid., paras 68, 69 and 70.

${ }^{34}$ Associação Sindical dos Juízes Portugueses, cited above.

${ }^{35}$ Ibid., para. 29.

${ }^{36}$ Ibid., para. 32.

${ }^{37}$ Ibid., para. 34 .
} 
"courts or tribunals" - must meet the requirements of effective judicial protection. This means, in essence, that such protection must be provided for by a body that falls within the notion of "court or tribunal" as defined by EU law. In particular, referring to its case law on Article 267 TFEU and on Article 47 of the Charter, the ECJ held that that notion requires courts to be independent.$^{38}$ After recalling what judicial independence means for the purposes of that case law, the ECJ found that "the receipt by those members of a level of remuneration commensurate with the importance of the functions they carry out constitutes a guarantee essential to judicial independence". ${ }^{39}$

As to the case at hand, the ECJ found, subject to final verification by the referring court, that the Tribunal de Contas could fall within the notion of "court or tribunal" as defined by EU law. ${ }^{40}$ Regarding the compatibility with the second subparagraph of Article 19(1) TEU of the salary-reduction measures at issue, the ECJ held, first, that those measures were adopted as a response to mandatory requirements linked to eliminating the Portuguese State's excessive budget deficit and in the context of an EU programme of financial assistance to Portugal. ${ }^{41}$ Second, the reduction of the amount of remuneration was limited to a percentage varying in accordance with the level of salary. ${ }^{42}$ Third, they were temporary in nature since by 2016 , the full reinstatement of the rights to remuneration at issue in the main proceedings had already taken place. ${ }^{43}$ Most importantly, the salary-reduction measures did not target the members of the Tribunal de Contas specifically, but applied to various public office holders as part of a comprehensive effort to cut down spending in the public sector at a time of economic crisis. ${ }^{44}$ As a result, the ECJ ruled that those measures could not be considered to impair the independence of the members of the Tribunal de Contas.

In my view, three direct implications flow from the judgment of the ECJ in Associação Sindical dos Juízes Portugueses. First, it shows that the scope of application of the second subparagraph Article 19(1) TEU is not the same as that of Article 47 of the Charter. The former applies to "the fields covered by EU law", whilst the latter applies to national measures implementing EU law within the meaning of Article 51(1) of the Charter. Second, where a national court qualifies as a "court or tribunal" as defined by EU law and such a court enjoys jurisdiction to rule

\footnotetext{
${ }^{38}$ Ibid., paras 42, 43 and 44. Regarding Article 47 of the Charter - which contains the notion of "independent and impartial tribunal" - the ECJ referred to ECJ judgments of 14 June 2017 in case C-685/15, Online Games and Others, EU:C:2017:452, para. 60; and of 13 December 2017 in case C-403/16, El Hassani, EU:C:2017:960, para. 40. As to the notion of "court or tribunal" set out in Article 267 TFEU, it referred to Wilson, cited above, para. 49, and Margarit Panicello, cited above, para. 37.

${ }^{39}$ Associação Sindical dos Juízes Portugueses, cited above, para. 45.

${ }^{40}$ Ibid., para. 40.

${ }^{41}$ Ibid., para. 46.

${ }^{42}$ Ibid., para. 47.

${ }^{43}$ Ibid., para. 50.

${ }^{44}$ Ibid., para. 49.
} 
on questions of EU law, that court acts as a "European court" and accordingly, EU law protects its independence. Last but not least, that judgment is a positive development in the law on judicial remedies. It shows that national courts are called upon to play a pivotal role in European integration, and that the ECJ is committed to upholding the rule of law within the EU.

\section{The Integrity of the Judicial Dialogue Between the ECJ and National Courts}

In order for the judicial dialogue between the ECJ and national courts to be effective, no field of EU law may be removed from the scope ratione materiae of the preliminary reference procedure. Where national courts apply the relevant provisions of EU law, they must have the possibility and, where appropriate, the obligation to engage in a dialogue with the ECJ. Otherwise, if either the EU political institutions or the Member States were able to remove a given field of EU law from the jurisdiction of national courts - and thereby from the scope of the preliminary reference procedure - the entire EU system of judicial protection, which is a defining feature of the EU and one of the principal guarantees of its autonomy, would be called into question.

As that system ensures the equal and uniform protection of rights across the EU, its integrity must be protected. This means, for example, that neither the EU political institutions nor the Member States may enter into an international agreement the effects of which would be to prevent the ECJ and national courts from engaging in dialogue in a given field of EU law.

For example, in Opinion $1 / 09,{ }^{45}$ the ECJ held that the draft agreement creating a Unified Patent Litigation System was not compatible with EU law, given that it conferred on an international court - which was outside the institutional and judicial framework of the EU - exclusive jurisdiction to hear a significant number of actions brought by individuals in the field of the Community patent and to interpret and apply European Union law in that field. That exclusive jurisdiction meant that all national courts would be deprived of their powers in relation to the interpretation and application of the relevant provisions of EU law and the ECJ of its powers to reply, by preliminary ruling, to questions referred by those courts.

Accordingly, the ECJ ruled that the EU could not ratify the agreement as drafted, since that agreement would alter the essential character of the powers which the Treaties confer on the institutions of the EU and on the Member States. More generally, it stressed the fact that all international agreements to which the EU becomes a party must ensure compliance with "the system set up by Article 267 TFEU [which] establishes between the [ECJ] and the national courts direct cooperation as part of which the latter are closely involved in the correct application and uniform

${ }^{45}$ ECJ Opinion 1/09 (Agreement creating a Unified Patent Litigation System) of 8 March 2011, EU:C:2011:123. 
interpretation of [EU] law and also in the protection of individual rights conferred by that legal order". ${ }^{46}$ Indeed, "the tasks attributed to the national courts and to the $[\mathrm{ECJ}]$ respectively are indispensable to the preservation of the very nature of the law established by the Treaties". ${ }^{47}$

More recently, in Achmea ${ }^{48}$ the ECJ reached the same conclusion, this time, however, in respect of a BIT concluded between two Member States, i.e. the Netherlands and the Slovak Republic (as a successor State to the Czech and Slovak Federative Republic). The BIT contained an arbitration clause entitling an investor from one of those two Member States, in the event of a dispute concerning investments in the other Member State, to bring proceedings against the latter Member State before an arbitral tribunal whose jurisdiction that Member State has undertaken to accept.

In the case at hand, following the Slovak Republic's decision to liberalise the private sickness insurance sector in 2004, Achmea, a company belonging to a Dutch insurance group, decided to invest in that Member State. However, in 2006, the Slovak Republic reversed the liberalisation of that sector, in particular by prohibiting the distribution of profits generated by private sickness insurance activities. That action caused financial harm to Achmea which decided to bring arbitration proceedings against the Slovak Republic. The parties chose Germany as the place of arbitration, meaning that the law of that Member State applied to those proceedings. The arbitral tribunal ordered the Slovak Republic to pay Achmea damages in the principal amount of EUR 22.1 million. The Slovak Republic challenged that award before the German courts which made a reference to the ECJ, asking, in essence, whether the arbitration clause set out in the BIT was compatible with EU law.

In order to provide an answer to the referring court, the ECJ decided to examine the three following questions: (1) whether the arbitral tribunal mentioned in the BIT was called upon to apply and interpret EU law; (2) whether that tribunal formed part of the EU judicial system, and (3) whether its own case law on commercial arbitration could be applied by analogy to the arbitration proceedings mentioned in the BIT.

First, although the arbitral tribunal was only called upon to rule on possible infringements of the BIT, the ECJ found that, in order for that tribunal to do so, it had to take account of the law applicable in the Contracting Party where the investment was made, including national, EU and international law. This meant that the arbitral tribunal could be called upon to interpret and apply rules and principles of EU law, in particular the freedom of establishment and the free movement of capital.

Second, the ECJ noted that the arbitral tribunal did not form part of the EU judicial system, since the very raison d'être of the arbitration clause contained in the BIT was precisely to prevent investor-related disputes from being submitted to the

\footnotetext{
${ }^{46}$ Ibid., para. 84.

${ }^{47}$ Ibid., para. 85 .

${ }^{48}$ Achmea, cited above.
} 
courts of the Contracting Parties. As a result, that tribunal could not be classified as a court or tribunal "of a Member State" within the meaning of Article 267 TFEU.

Thirdly, the ECJ observed that the arbitral award was final and the question whether that award was subject to review by a court of a Member State - thereby ensuring the potential application of the preliminary reference mechanism - had to be examined in the light of the law of the country chosen as the place of arbitration. For the case at hand, that country was Germany, whose law only provided for limited review of arbitral awards.

At this point, the ECJ drew an important distinction between commercial arbitration proceedings and arbitration proceedings such as those mentioned in the BIT. In relation to commercial arbitration proceedings, which are the result of the express wishes of the parties, the ECJ has held that the efficiency of those proceedings may justify a limited review, "provided that the fundamental provisions of EU law can be examined in the course of that review and, if necessary, be the subject of a reference to the $[E C J]$ for a preliminary ruling". By contrast, such considerations could not be applied to the arbitration proceedings mentioned in the BIT. This is because "[those proceedings] derive from a treaty by which Member States agree to remove from the jurisdiction of their own courts, and hence from the [EU] system of judicial remedies [...] disputes which may concern the application or interpretation of EU law". In view of the ECJ, such removal "could prevent those disputes from being resolved in a manner that ensures the full effectiveness of EU law, even though they might concern the interpretation or application of that law". ${ }^{49}$ Accordingly, the ECJ ruled that the arbitration clause set out in the BIT had an adverse effect on the autonomy of EU law.

The ruling of the ECJ in Achmea is an important development in the case law of the ECJ, both in terms of international investment law and in terms of the law of the EU on remedies. It highlights the distinction between commercial arbitration proceedings and arbitration proceedings provided for in BITs. Most importantly, just as the ECJ ruled in its Opinion 1/09, the autonomy of EU law precludes an international agreement entered into by the Member States the effect of which would be to remove from the jurisdiction of national courts - and thus from the scope of the preliminary reference procedure - disputes that may involve the application and interpretation of EU law. Achmea makes absolutely clear that the application of EU law at national level and judicial dialogue must always go hand-in-hand.

\section{Judicial Independence and Mutual Trust in the AFSJ}

In the establishment of an AFSJ, the principle of mutual trust is "of fundamental importance" 50 since it guarantees that the exercise of free movement does not undermine the effectiveness of the decisions adopted by the competent Member State (whose public power is often exercised on a territorial basis). As internal borders

\footnotetext{
${ }^{49}$ Ibid., para. 55.

${ }^{50}$ Opinion 2/13 (Accession of the European Union to the ECHR), para. 191.
} 
disappear, the principle of mutual trust enables the arm of the law to become longer by acquiring a transnational reach.

In setting up the AFSJ, the authors of the Treaties took the view that national courts were best placed to protect the (fundamental) rights of individuals since they are insulated from political considerations and are, in cooperation with the ECJ, entrusted with the task of upholding the rule of law within the EU. That is why the establishment of the AFSJ is, first and foremost, to be achieved through the mutual recognition of national judicial decisions. Mutual recognition of those decisions implies that the court where recognition and enforcement is sought should trust that the court that adopted the decision in question provided effective judicial protection to the persons concerned by that decision, including, in particular, protection of their fundamental rights.

\subsection{Judicial Independence and the Notion of "Court" in the AFSJ}

Accordingly, for the purposes of the free movement of judicial decisions, the notion of "court" (or "tribunal") is of paramount importance, as it is that notion that determines the bodies whose decisions qualify for mutual recognition.

To that effect, the notion of "court" must be construed in the light of the principle of mutual trust. Just like in the context of Article 267 TFEU, this means, in essence, that the notion of "court" within the AFSJ requires the body in question to be impartial and independent. This point is illustrated by looking at the judgments of the ECJ in Pula Parking and Baláž. Whilst the first case relates to judicial cooperation in civil matters, the latter concerns judicial cooperation in criminal matters.

In Pula Parking, ${ }^{51}$ the ECJ was asked to interpret the notion of "court" within the meaning of the new Brussels I Regulation. ${ }^{52}$ More specifically, the question that arose was whether, in respect of enforcement proceedings based on an "authentic act", a Croatian notary could be considered as "a court" within the meaning of that Regulation. The ECJ replied in the negative.

At the outset, the ECJ noted that in the absence of any reference to the law of the Member States, the notion of 'court' had to be interpreted autonomously, taking into account the overall scheme, the objectives and the origin of the new Brussels I Regulation. ${ }^{53}$ It observed that that Regulation sought to facilitate the mutual recognition of judicial decisions in civil and commercial matters as if those decisions had been delivered in the Member State in which enforcement is sought. ${ }^{54}$ In order for

\footnotetext{
${ }^{51}$ ECJ judgment of 9 March 2017 in case C-551/15, Pula Parking, EU:C:2017:193.

${ }^{52}$ Regulation (EU) No 1215/2012 of the European Parliament and of the Council of 12 December 2012 on jurisdiction and the recognition and enforcement of judgments in civil and commercial matters, [2012] OJ L 351/1.

${ }^{53}$ Ibid., para. 42.

${ }^{54}$ Ibid., para. 52.
} 
the Member State of enforcement to treat judicial decisions from other Member States as if they were its own - a degree of equal treatment that unequivocally achieves simplicity and efficiency in the recognition and enforcement of judgments the ECJ reasoned that there must be mutual trust in the administration of justice in the Union.

Accordingly, "the concept of "court" for the purposes of [the new Brussels I Regulation] must be interpreted as taking account of the need to enable the national courts of the Member States to identify judgments delivered by other Member States' courts and to proceed, with the expeditiousness required by that regulation, in enforcing those judgments". Thus, in the key passage of that judgment, the ECJ wrote that "[c]ompliance with the principle of mutual trust in the administration of justice in the Member States of the European Union which underlies that regulation requires, in particular, that judgments the enforcement of which is sought in another Member State have been delivered in court proceedings offering guarantees of independence and impartiality and in compliance with the principle of audi alteram partem". ${ }^{55}$ Put differently, only courts of the Member State of origin that fulfil those guarantees and comply with that principle are worthy of the trust of the courts of the Member State of enforcement.

However, this was not the case as regards Croatian notaries who, apart from the fact that they do not form part of the Croatian judicial system, may issue "a writ of execution based on an 'authentic document' [that] is served on the debtor only after the writ has been adopted, without the application by which the matter is raised with the notary having been communicated to the debtor". ${ }^{56}$ Since the adoption of such a writ fails to comply with the principle of audi alteram partem, Croatian notaries could not be seen in this context as "courts" within the meaning of the new Brussels I Regulation.

In Baláž ${ }^{57}$ the ECJ was called upon to interpret the notion of a "court having jurisdiction in particular in criminal matters" for the purposes of Framework Decision 2005/214. ${ }^{58}$ That Framework Decision seeks to establish an effective mechanism for recognition and cross-border execution of final decisions requiring a financial penalty to be paid by a natural person or a legal person following the commission of one of the offences listed in Article 5 thereof. To that end, those decisions may be adopted by an authority other than a court (i.e. an administrative authority), provided that the person concerned has had an opportunity to have the case tried by "a court having jurisdiction in particular in criminal matters". The ECJ relied on the case law relating to Article 267 TFEU when interpreting the notion of "court" within the meaning of that Framework Decision. ${ }^{59}$ Next, it held that the

\footnotetext{
${ }^{55}$ Ibid., para. 54.

${ }^{56}$ Ibid., para. 57.

${ }^{57}$ ECJ judgment of 14 November 2013 in case C-60/12, Baláž, EU:C:2013:733.

${ }^{58}$ Council Framework Decision 2005/214/JHA of 24 February 2005 on the application of the principle of mutual recognition to financial penalties, [2005] OJ L 76/16, as amended by Council Framework Decision 2009/299/JHA of 26 February 2009, [2009] OJ L 81/24.

${ }^{59}$ Baláž, cited above, para. 32 .
} 
terms "jurisdiction in particular in criminal matters" were to be interpreted bearing in mind that, as regards some of the offences to which Framework Decision 2005/214 applies, the Member States may provide for either administrative or criminal offences. This was the case of the offences at issue in the main proceedings, i.e. offences relating to "conduct which infringes road traffic regulations". Accordingly, the terms "jurisdiction in particular in criminal matters" not only referred to a court that has jurisdiction in criminal matters alone, but also to a court that applies "a procedure which satisfies the essential characteristics of criminal procedure". ${ }^{60}$

It follows from the rulings of the ECJ in Pula Parking and Baláz that there is a degree of consistency between the notion of "court" within the meaning of Article 267 TFEU and that applied in EU legislation adopted in the AFSJ, in so far as those notions both have the requirement of judicial independence as their central feature. Regarding judicial independence, the same consistency applies as between Article 267 TFEU and Article 47 of the Charter. For example, in El Hassani, a case concerning the EU Visa Code, the ECJ interpreted the notion of an "independent and impartial tribunal" within the meaning of Article 47 of the Charter by referring to the Wilson line of case law. ${ }^{61}$ Such overall consistency is a positive development, showing that supranational justice and transnational justice are not applying double standards when it comes to requiring independent courts.

More broadly speaking, when interpreting the notion of "court", AG Bobek pointed out in Pula Parking that "[t]here are good normative and pragmatic reasons not to reinvent the wheel". "Normatively", he wrote, "coherency in the law is an important element of predictability and legality". "Pragmatically speaking", he argued, "the Article 267 TFEU test already captures quite well the quintessential characteristics of a body of judicial nature that could be referred to as a "court or tribunal". ${ }^{62}$ Moreover, the reasons put forward by AG Bobek find an echo in the rulings of the ECJ in cases such as Wilson and Torresi. In those cases, the ECJ gave impetus to this idea of semantic consistency, since they bear witness to interpretative crossover between the notion of "court" within the meaning of Article 267 TFEU and the same notion as applied in secondary EU legislation. ${ }^{63}$ Furthermore, the EU legislator also favours such consistency. ${ }^{64}$

\footnotetext{
${ }^{60}$ Ibid., para. 36.

${ }^{61}$ El Hassani, cited above, para. 40. See also Opinion of Advocate General Bobek in El Hassani, cited above, EU:C:2017:659, point 121.

${ }^{62}$ Opinion of Advocate General Bobek in Pula Parking, cited above, EU:C:2016:825, point 100.

${ }^{63}$ Wilson, cited above, paras. 49-52. That judgment does not concern the notion of "court or tribunal" within the meaning of Article 267 TFEU but within the meaning of Directive 98/5/EC of the European Parliament and of the Council of 16 February 1998 to facilitate practice of the profession of lawyer on a permanent basis in a Member State other than that in which the qualification was obtained, [1997] OJ L 77/36. However, in Wilson, the ECJ explicitly referred to its case law on Article 267 TFEU. Ibid., para. 48. Subsequently, the ECJ applied its main findings in Wilson - i.e. that judicial independence has an external and internal aspect - in the context of Article 267 TFEU. See, e.g., ECJ judgment of 17 July 2014 in joined cases C-58/13 and C-59/13, Torresi, EU:C:2014:2088, paras 96 and 97.

${ }^{64} \mathrm{ECJ}$ judgment of 31 January 2013 in case C-175/11, D. and A., EU:C:2013:45, para. 81.
} 
However, the principle of mutual trust may set some limits to such consistency. As AG Bobek also noted in Pula Parking, "avoiding a complete reinvention of the wheel does not preclude the modification or adaptation of its use". ${ }^{65}$ In particular, the proper operation of the principle of mutual trust may require the application of a criterion that is not absolute under Article 267 TFEU. ${ }^{66}$ This is the case of the principle of audi alteram partem, compliance with which is not mandatory under that Treaty provision, but is considered to be absolute in order for courts to trust each other in the context of the new Brussels I Regulation. Indeed, whilst "it may well be in the interests of the proper administration of justice for a preliminary question not to be referred until after an inter partes hearing, ... it must be recognized that the existence of an inter partes hearing does not appear among the conditions required to implement the procedure under Article [267 TFEU, since] it is for the national court alone to assess the need to hear the defendant before making an order for reference". ${ }^{67}$ By contrast, since it is precisely the proper administration of justice that facilitates mutual trust between the courts of different Member States, the application of mutual recognition in the context of the new Brussels I Regulation requires such an inter partes hearing.

\subsection{Judicial Independence and the Notion of 'Judicial Authority' in the Context of the European Arrest Warrant}

The EU legislator may decide to apply the principle of mutual recognition not only to decisions adopted by courts but also by authorities that participate in the administration of criminal justice. This is the case of the European Arrest Warrant Framework Decision, ${ }^{68}$ which provides that in order for an EAW to be enforced and recognised in the executing Member State, such an arrest warrant must be issued by a "judicial authority", understood as an authority that is independent from the executive. ${ }^{69}$ This is because the mutual recognition of EAWs is predicated on a high level of trust that is not justified unless the issuing of an arrest warrant is subject to judicial approval. This was made clear by the ECJ in a series of cases dealt with under

\footnotetext{
${ }^{65}$ Opinion of Advocate General Bobek in Pula Parking, cited above, point 102.

${ }^{66}$ See, e.g., ECJ judgment of 25 June 2009 in case C-14/08, Roda Golf \& Beach Resort, EU:C:2009:395, paras 33-34.

${ }^{67}$ See ECJ judgment of 3 March 1994 in joined cases C-332/92, C-333/92 and C-335/92, Eurico Italia and Others, EU:C:1994:79, para. 11.

${ }^{68}$ Council Framework Decision 2002/584/JHA of 13 June 2002 on the European arrest warrant and the surrender procedures between Member States, [2002] OJ L 190/1, as amended by Council Framework Decision 2009/299/JHA of 26 February 2009, [2009] OJ L 81/24.

${ }^{69}$ See ECJ judgments of 10 November 2016 in case C-452/16 PPU, Poltorak, EU:C:2016:858; in case C-477/16 PPU, Kovalkovas, EU:C:2016:861, and in case C-453/16 PPU, Özçelik, EU:C:2016:860.
} 
the urgent preliminary procedure that were decided on the same day, i.e. Poltorak, Kovalkovas, and Özçelik.

Those three cases involved, respectively, the execution of an EAW issued by the Swedish police board for the purposes of executing a custodial sentence, that of an EAW issued by the Lithuanian Ministry of Justice for the purposes of executing a custodial sentence, and that of an EAW issued in the context of criminal proceedings by the Hungarian police and confirmed by the Hungarian public prosecutor's office ("PPO").

In Poltorak, the case concerning the EAW issued by the Swedish police board, the ECJ examined the term "judicial authority" as set out in Article 6(1) of the EAW Framework Decision, a provision that states that " $[t]$ he issuing judicial authority shall be the judicial authority of the issuing Member State which is competent to issue [an EAW] by virtue of the law of that State".

At the outset, the ECJ held that the reference made to the law of the issuing Member State is limited to the designation of the judicial authority having the competence to issue EAWs. Accordingly, that reference does not concern the definition of the term "judicial authority" itself. This is because the meaning and scope of that term could not be left to the assessment of each Member State but rather required an autonomous and uniform interpretation..$^{70}$ In that regard, the ECJ relied on a textual, contextual and teleological interpretation of Article 6(1) of the EAW Framework Decision in order to give meaning to that term.

Textually, the ECJ observed that the words "judicial authority", contained in that provision, are not limited to designating only the judges or courts of a Member State, but may extend, more broadly, to the authorities required to participate in administering criminal justice in the legal system concerned. ${ }^{71}$ However, it also noted that it is generally accepted that the term "judiciary" does not cover police services. That term refers to the judiciary, which must be distinguished, in accordance with the principle of the separation of powers which is intimately connected to the operation of the rule of law, from the executive. Thus, judicial authorities are traditionally those authorities that administer justice, unlike, inter alia, administrative authorities or police authorities, which fall within the sphere of the executive. ${ }^{72}$

Contextually, when the EAW Framework Decision was adopted, the Treaties themselves drew a distinction between police cooperation and judicial cooperation in criminal matters, as each type of cooperation was defined in a separate Treaty provision, namely ex Articles 30 and $31 \mathrm{EU} .{ }^{73}$

Teleologically, the principle of mutual recognition - as given concrete expression in the context of the EAW - operates on the premise that a judicial authority has intervened prior to the execution of the EAW. This is because it is such judicial

\footnotetext{
${ }^{70}$ Poltorak, cited above, para. 32 .

${ }^{71}$ Ibid., para. 33.

${ }^{72}$ Ibid., paras. 34 and 35.

${ }^{73}$ Ibid., para. 37. Currently, each type of cooperation is defined in a separate Chapter of the Title relating to the AFSJ (i.e. Title V of Part Three of the TFEU), namely Chapter 4 (Articles 82 to 86 TFEU) for judicial cooperation and Chapter 5 (Articles 87 and 88 TFEU) for police cooperation.
} 
intervention that justifies the high level of trust between the Member States that is required for the successful operation of that principle. ${ }^{74}$

As a result, the ECJ ruled that the term "judicial authority", within the meaning of the EAW Framework Decision, must be interpreted as meaning that police services are not covered by that term. Nor can an EAW issued by such services be regarded as a "judicial decision" within the meaning of that Framework Decision.

Similarly, in Kovalkovas, the case concerning the EAW issued by the Lithuanian Ministry of Justice, the ECJ found that such an EAW was not to be regarded as issued by a "judicial authority". Nor could it be regarded as a "judicial decision" within the meaning of the EAW Framework Decision. That was so because it was ultimately for the Ministry of Justice to take a decision on issuing the EAW and not for the judge imposing the custodial sentence. ${ }^{75}$ Accordingly, such a decision was not subject to judicial approval.

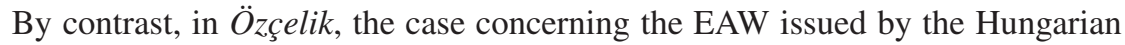
police and confirmed by the Hungarian PPO, the questions referred focused on the term "judicial decision" rather than on the term "judicial authority". However, that made no difference. In order to ensure consistency between the various provisions of the EAW Framework Decision, the ECJ held that the same rationale applied. This meant that the term "judicial decision" covered decisions of the Member State authorities that administer criminal justice, but not police services.

In the $\ddot{O}$ zçelik case, the intervention of the PPO proved, however, to be decisive. Under Hungarian law, the PPO verifies and validates the arrest warrant issued by the police, so that it is that office that is to be assimilated with the issuer of that arrest warrant. Recalling its previous case law, the ECJ found that the PPO constitutes a Member State authority for the purposes of administering criminal justice. ${ }^{76}$ Thus, unlike the EAWs issued in Poltorak and Kovalkovas, the ECJ found that the EAW issued by the Hungarian police and confirmed by the PPO constituted a "judicial decision" within the meaning of the EAW Framework Decision.

As pointed out by AG Campos Sánchez-Bordona, it seems that the notion of "judicial authority" is broader than that of "court or tribunal" within the meaning of Article 267 TFEU. Indeed, the PPO may not make a reference to the ECJ, since it is not called upon "to rule on an issue in complete independence but, acting as prosecutor in the proceedings, to submit that issue, if appropriate, for consideration by the competent judicial body". ${ }^{77}$ The fact that the EU legislator opted for the concept of "judicial authority" instead of that of "court" may be explained by the fact that EU law allows room for diversity in the criminal procedural law of the Member

\footnotetext{
${ }^{74}$ Ibid., paras 44 and 45 .

${ }^{75}$ Kovalkovas, cited above, para. 47.

${ }^{76}$ Özçelik, cited above, para. 34 (referring to ECJ judgment of 29 June 2016 in case C-486/14, Kossowski, EU:C:2016:483, para. 39).

${ }^{77}$ Opinion of Advocate General Campos Sánchez-Bordona in Özçelik, cited above, EU:C:2016:783, point 62 (referring to ECJ judgment of 12 December 1996 in joined cases C-74/95 and C-129/95, X, EU:C:1996:491, para. 19).
} 
States when it comes to choosing between the inquisitorial and adversarial criminal systems, the latter giving a more prominent role to an authority such as the PPO than the former. However, extending the application of the principle of mutual recognition beyond the notion of "courts" requires compliance with the principle of mutual trust. This meant, in Özçelik, that the EAWs confirmed by the PPO could only benefit from free movement because that office was independent from the executive and participated in the administration of justice.

\section{Concluding Remarks}

It follows from the foregoing paragraphs that the notion of "court or tribunal" set out in Article 267 TFEU provides the ECJ with the general framework of analysis that facilitates the interpretation of that same notion in different normative contexts. Whilst such a framework may guarantee normative consistency, its application must be subject to some degree of flexibility in order to allow the ECJ to interpret the notion of "court" in the light of the objectives pursued by the EU act in question. In the AFSJ, this means, as the ruling of the ECJ in Pula Parking shows, that the notion of "court" must be construed, first and foremost, in keeping with the principle of mutual trust.

That said, that degree of flexibility does not affect judicial independence, since, in the EU legal order, a "court" is always to be understood as meaning an "independent court". Judicial independence is thus a prerequisite for any "court" that wishes to engage in a dialogue with the ECJ and with sister courts in other Member States. From a supranational perspective, independent courts guarantee the effective and loyal application of EU law, as interpreted by the ECJ. From a transnational perspective, mutual trust between national courts can only take place where those courts are independent, as only then will those courts see each other as equals.

Since the enforcement of EU law is decentralised, the entire EU system of judicial protection is thus predicated on the premise that the Member States enjoy and cherish an independent judiciary that is capable of providing effective judicial protection of EU rights. However, where that premise no longer holds true, i.e. where judicial independence is lacking, the preliminary reference procedure becomes devoid of purpose, and the principle of mutual trust no more than an empty promise. Should that happen, then a link in the chain of European justice would be broken and the rule of law within Europe as a whole would inevitably be weakened as a result.

That is the reason why, in the fields covered by EU law, the second subparagraph of Article 19(1) TEU imposes on the Member States the obligation to refrain from adopting any measures that may threaten the independence of their own judiciaries. Any such measures are repugnant to the values on which the EU is founded and must be set aside. Thus, as the ruling in Associação Sindical dos Juízes Portugueses shows, the ECJ, as the ultimate guarantor of the rule of law within the EU, is 
genuinely committed to preserving the independence of the Member State judiciaries. The reason is simple: without it, justice will not prevail, be it from a national, a supranational, or a transnational perspective.

\section{References}

Broberg M, Fenger N (2014) Preliminary references to the European Court of Justice. Oxford University Press, Oxford

De Witte B et al (eds) (2016) National courts and EU law: new issues, theories and methods. Edward Elgar Publishing, Cheltenham

Lenaerts K (2017) La vie après l'avis: exploring the principle of mutual (yet not blind) trust. Common Mark Law Rev 54(3):805-840 